\title{
Computer-informative software for research of the new materials of constructional applications
}

\author{
Yu.Kuts, O.Povstyanoy \\ Department of computer machine-tools design and machine-building \\ technologies, Lutsk National Technical University, \\ 75 Lvivska Str., 43018 Lutsk, Ukraine
}

Received October 16, 2016

\begin{abstract}
This article describes the main processes of deposition of combined a protective coating on the machine parts. Characterization of the coating process, which includes electric metallization followed by synthesis, was presented. Microstructure and performance of the protective coatings for structural parts of constructional applications from powder obtained from industrial wastes were studied. The aim of this paper is to analyze the main methods to protect surfaces of constructional purposes which obtained from powder of industrial wastes and to explore the process of applying of such a coating that meets modern requirements.
\end{abstract}

Keywords: protective coatings, industrial wastes, metallization, oxide ceramic coating, wear resistance.

Изложены методы нанесения комбинированного защитного покрытия на детали. Данная характеристика процесса нанесения покрытия включает в себя электродуговую металлизацию с последующим синтезом. Изучены микроструктуры и эксплуатационные характеристики защитных покрытий деталей конструкционного назначения из порошков, полученных из отходов промышленного производства. Проанализированы основные методы защиты поверхностей деталей конструкционного назначения, которые получены из порошков отходов промышленного производства, изучен процесс нанесения такового покрытия, который отвечает современным требованиям.

Комп'ютерно-інформаційне забезпечення при дослідженні нових матеріалів конструкційного призначення. Ю.Куц, О.Повстяной.

Описано основні процеси нанесення комбінованого захисного покриття на деталі. Дана характеристика процесу нанесення покриття включає в себе електродугову металізацію з подальшим синтезом. Вивчено мікроструктури і експлуатаційні характеристики захисних покриттів деталей конструкційного призначення 3 порошків, отриманих з відходів промислового виробництва. Проаналізовано основні методи захисту поверхонь деталей конструкційного призначення, які отримано 3 порошків відходів промислового виробництва, досліджено процес нанесення такого покриття, який відповідає сучасним вимогам.

\section{Introduction}

Swift development of computing engineering and methods of digital processing of images gave an opportunity considerably extend automation of research works in many areas of science. Macroscopic materials' behaviour directly depends on the features of their microstructure. The quantitative approach the analysis allows revealing that optimal structure that in the most measure answers the terms of materials service. 
Study of structural characteristics of metals and alloys is one of the key tasks of modern material science, based on which the process of creating the new and improving properties of existing materials is going on. Studying the capabilities and evaluating the modern software for computer research of metallography images with the aim of quality and quantitative descriptions of determinations of various materials by scientific and productive tasks that arose up is dictated in modern materials' science today [1-3].

In the arsenal of the modern software there are all necessary technical image processing algorithms, high-frequency and lowfrequency filtration, selection borders of images, arithmetic and logical operations, correction of brightness / contrast and so on. Image processing in this case is not aimed at improving the visual perception and focused on its preparations for further analysis.

\section{Experimental}

According to trend of the modern technology we developed the high-quality composite materials and coatings with complex of high physical and mechanical characteristics of the new topical powders, which from such compositions are formed.

As source material we used grinding steel sludge BBS15 formed after machining rings and roller bearings in terms of PJSC "SKF Ukraine". Grinding steel BBS15 sludge contains a significant amount of iron oxides and chromium products abrasion grinding wheels, and various oils, synthetic fluids, water, members of the coolant.

To obtain the high-quality powder BBS15 we applied the new patented technology, where the main difference from existing alteration's sludge industrial wastes is that after the chopping formed by heat the conducting of additional growing-rolling-off to the ball mill took place to give powder particles smaller and regular spherical form [4-6]. The high-quality powder particles with regular shape and size, with high technological properties were obtained by the metal powder technology.

For applying the corrosion protective coating on the details of construction designation it is commonly used the method of plasmas electrolytic oxidation (PEO), which is one of the most modern and advanced methods for metals surface and alloys protective layers and it has set important characteristics $[7,8]$.

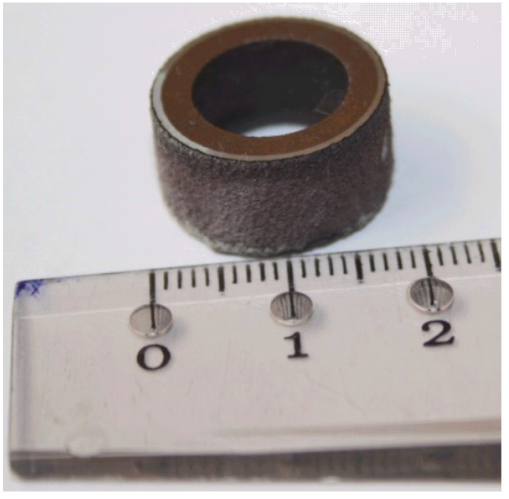

Fig. 1. General view of bushings after applying the combined coverage.

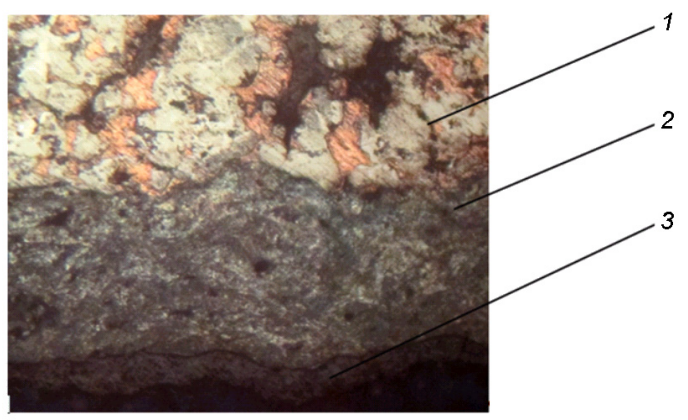

Fig. 2. Microstructure of samples-bushings $(\times 100)$.

Research experiments were conducted on four samples - bushing, which were made of industrial wastes (powder steel BBS15). For this prior and etched micro-sections were done. Digestion of the samples by herbalist $-0.5 \ldots 3 \%$ alcoholic solution of hydrofluoric acid HF was carried out.

\section{Results and discussion}

At the beginning a general view of the sample was obtained after applying for it combined coverage (Fig. 1). The samples have a similar appearance, but inflicted on them coating has different thicknesses and different modes of PEO, so leads only one photo.

In Fig. 2 we can see the limit of the base metal in the upper (position 1), and lower dark gray that shows the electro metal cover (position 2) and plasma electrolytic oxidized coating (position 3 ).

The boundary between the base metal and electric arc coating is clearly expressed, but not uniform.

Micro structure of the plasma electrolytic oxidized coatings is characterized by homogeneous structure and peculiar porosity. After digestion it can be seen a clear line distribution of electro metallic coating and 
coating, which plasma electrolytic oxidation is formed. This is typical for all samples.

The combined sheeting forms an electro deposited metallic layer and plasma electrolyte by ceramic oxide layer. The thickness of each coating by measurements in three places and determination of the average value of thickness for each coating were determined. By adding the average thickness of the electric and PEO coating it was found the average thickness of the combined protective coating.

To determine micro hardness we used of micro hardness tester PMT-3. We determined the micro hardness of the base metal, electrical arc and plasma electrolytic oxidized surfaces by applying the three jabs in each area (two pricks made on the edges and in the middle of the coating or base metal). When pressures remained prints from indenter (diamond pyramid) were obtained. We measured the prints diagonal and framed in the formula. So it was found the micro hardness each of samples.

It was give the result generalized graphics of the micro hardness changes from the base metal and coating cover. Numerical data of the micro hardness mean values for the base metal, electro metallic and PEOcoating are shown in Table.

From Fig. 3 it is seen the micro hardness change depending on the coating method. Micro hardness first arc comes to the surface, and then begins to grow very rapidly, moving to the PEO coverage.

Among the most progressive and most productive applied programs for processing and analyzing of metallographic images with the ability to visualize three-dimensional objects on two-dimensional photo-
Table. The average value of micro hardness of samples made of industrial wastes

\begin{tabular}{||c|c|c|c||}
\hline \multirow{2}{*}{ Sample } & \multicolumn{3}{|c|}{ Coating } \\
\cline { 2 - 4 } & Base metal & $\begin{array}{c}\text { Electric arc } \\
\text { cover }\end{array}$ & PEO-covering \\
\hline No. 1 & 592.8 & 327 & 3876.5 \\
No. 2 & 653.3 & 295.6 & 8305 \\
No. 3 & 736.3 & 613,6 & 4616 \\
No. 4 & 991.6 & 1526.6 & 7157 \\
\hline
\end{tabular}

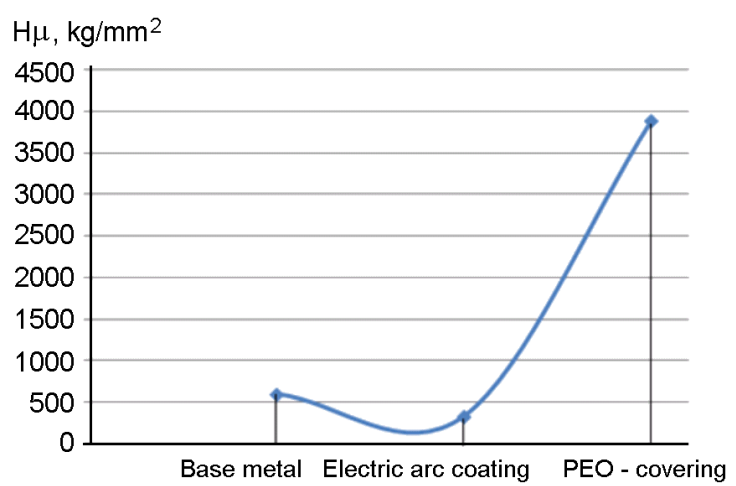

Fig. 3. Generalized dependence of change of micro hardness of the coating method for bushings, which are made of industrial wastes.

graphs is Avizo ${ }^{\circledR}$. So to test our samples to the reliability of the results we applied the software methods [9, 10].

The same actions were performed with the etched sample.

\section{Conclusion}

Modern computer and information technology for the analysis of micro image is a universal tool for qualitative image analysis in

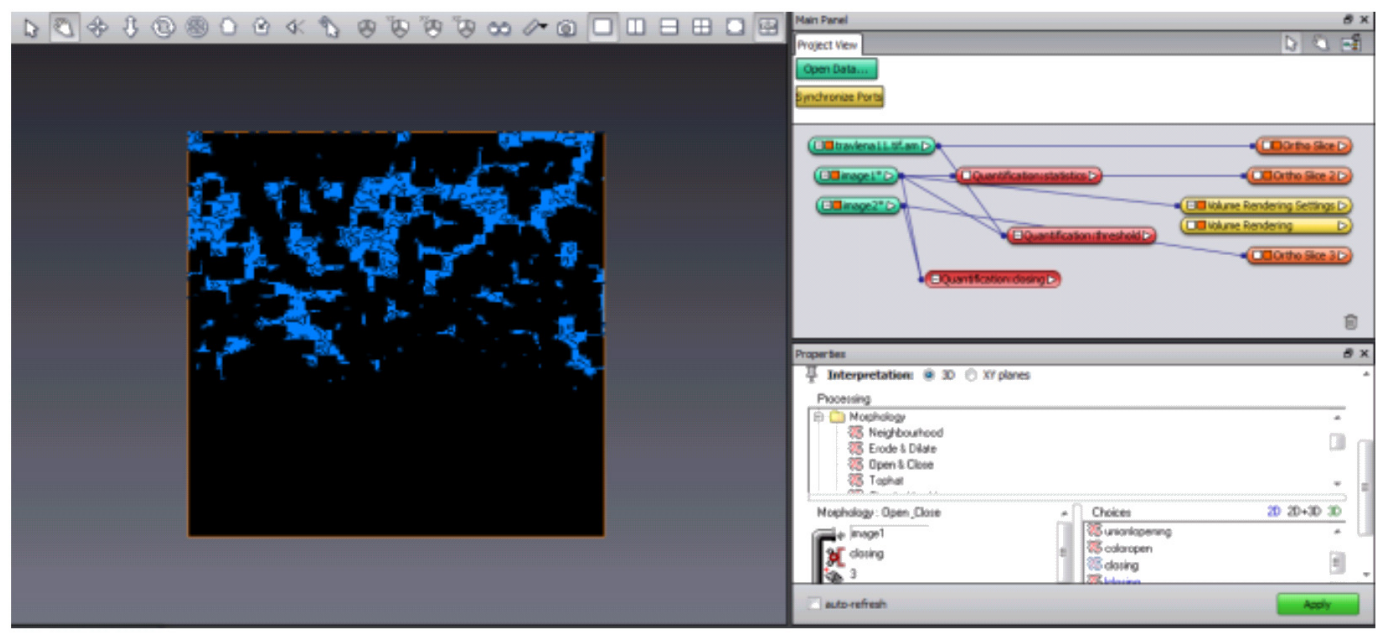

Fig. 4. Cut bushings with coating. 


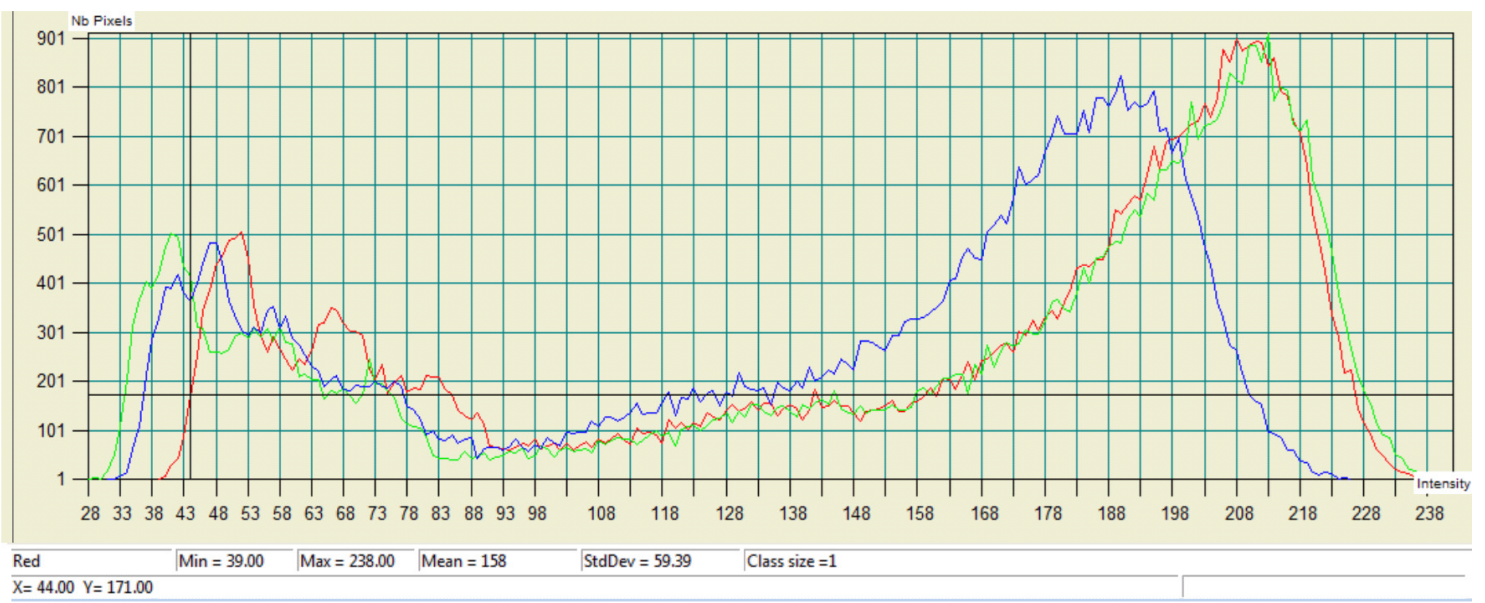

Fig. 5. Generalization histogram changes of micro hardness of the coating method for bushings, which are made of industrial wastes.

the modern science and industry. It is indispensable both in laboratory analysis of structures and the quantitative analysis in accordance with Ukrainian and international standards.

Based on the analyiis of scientific literature and previous studies it is shown that the methods of powder metallurgy enable the creation of anti-friction composite materials from industrial wastes with different constituents of various structural components included in the material (in particular steel powder BBS15).

In the process of experimental studies the following main characteristics of coatings were found: the largest combined thickness of the protective coating bushings is equal to $63.7 \mu \mathrm{m}$; the largest micro arc coating hardness bushings is $H_{\mu}=$ $1526.6 \mathrm{~kg} / \mathrm{mm}^{2}$, and the greatest micro hardness plasma electrolytic oxidized coating bushings is $H_{\mu}=1526.6 \mathrm{~kg} / \mathrm{mm}^{2}$.

Checking the accuracy of the experimental research was done using the modern software Avizo $^{\circledR}$. The margin of error was $5 \%$.
Generalization that samples-bushings micro hardness begins to increase after plasma electrolytic oxidation is proved.

\section{References}

1. H.M.Nykyforchyn, V.S.Agarwala, M.D.Klapkiv, V.M.Posuvailo, Adv.Mater.Res., 38, 27 (2008).

2. R.S.Lima, B.R.Marple, J. Thermal Spray Technol., 16, 40 (2007).

3. J.P.Cai, B.Li, Mater.Mech.Eng., 24, 5 (2000).

4. Ukraine patent 63,558 (2004).

5. A.F.De Araujo, C.E.Constantinou, J.M.R.Tavares, Expert Syst., 41, 5892 (2014).

6. A.A.Samarsky, A.P.M.Mikhajlov, Mathematical Modeling: the Ideas. Methods. Examples, Nauka, Fizmatlit, Moscow (1997) [in Russian].

7. V.Pokhmurskii, G.Nykyforchyn, M.Student et al., J. Thermal Spray Techn., 16, 998 (2007).

8. J.A.Curran, T.W.Clyne, Surf. Coat.Tech., 168 (2005).

9. http://www.vsg3d.com

10. http://www.avizo3d.com 